УДК821.091(100):7.035

Шевців Г. М., кандидат філолологічних наук, старший викладач кафедри практики німецької мови Дрогобицький державний педагогічний університет ім. Івана Франка

\title{
ЛІТЕРАТУРНА ПРЕЗЕНТАЦІЯ ДИТИНСТВА В ЄВРОПЕЙСЬКОМУ СПОГАДОВОМУ ПИСЬМІ: ВІД ПРОСВІТНИЦТВА ДО РОМАНТИЗМУ
}

Статтю присвячено розгляду питання літературної презентації періоду дитинства в європейському спогадовому письмі XVIII-XIX століть. Проаналізовано літературну концепцію та окремі наративні моделі дитинства європейських авторів XVIII-XIX століть. Підкреслено особливий зміст теми дитинства творів періоду романтизму.

Ключові слова: автобіограф, автор, виховання, дитинство, образ, концепція.

The article deals with the literary presentation of childhood in European memoirs in the XVIII-XIX century issue. The literary concept and separate narrative models of childhood of European authors of the XVIII-XIX century are analyzed. Particular meaning of the childhood issues in works of the romantic period is underlined.

Key words: autobiography, author, education, childhood, image, conception.

Статья посвящена рассмотрению вопроса литературной презентации периоду детства в европейском автобиографическом письме XVIII-XIX веков. Проанализирована литературная кониепџия и отдельные нарративные модели детства европейских авторов XVIII-XIX веков. Подчеркнуто особенное содержание темь детства произведений периода романтизма.

Ключевые слова: автобиограф, автор, воспитание, детство, образ, концепџия. 
Тема дитинства - одна 3 центральних тем світової художньої літератури та літератури факту. Це універсальна тема, яка не обмежена рамками певної національної літератури чи конкретного часового періоду. Концепція дитинства та його літературна презентація в автобіографічних творах кардинально змінювалися протягом багатьох віків. Наукове вивчення динаміки концепцій дитинства та дитячих образів у літературі надає цінну інформацію про європейську культуру та ментальність. В історії людства ставлення до дитини, відповідно до теми дитинства в художній творчості, зокрема в спогадовій літературі, постійно змінювалося: від байдужого, авторитарного (Античність, Середні віки, початок Нового часу) до відверто «дитиноцентричного» (ХІХ століття - по сьогоднішній день).

Об’єктом дослідженняу статті $є$ концепція дитинства в європейському спогадовому письмі XVIII-XIX століть.

Предметом дослідженняє тексти автобіографічних творів Л. Стерна, Ж.-Ж. Руссо, Й.-В. Гете.

Метою нашого дослідження $є$ аналіз літературної концепції загалом та окремих наративних моделей дитинства європейських авторів XVIII-XIX століть.

Початки зламу в ставленні до дітей та дитинства чітко пов’язані зі зміною ментальних структур загалом від часу Ренесансу та Реформації. Ці яскраві зрушення виявилися у державній політиці та суспільних процесах значно пізніше, за доби Просвітництва. Саме воно, щосили долаючи схоластику, дало нам сучасне розуміння виховання, освіти й ставлення до дитини. Еволюція була повільною i перепліталася 3 традиційними устоями, але впродовж кількох століть ऑï вплив був істотним і разючим. Сучасні моделі поведінки, система навчання й контролю, прагнення до раціональності - все це продукти епохи Просвітництва.

Осмислення розглядуваної проблеми неможливе без звернення до психології, соціології, культурології та етнографії (Ф. Арієс, К. Ізвард, І. Кон, М. Осоріна, Т. Стефанченко). Психологи зазначають, що образ дитинства в 
художньому творі читач розуміє як сукупність уявлень дорослої людини про дитинство. Він виконує функції своєрідного дзеркала стосовно дорослої людини [Бондарева 2006, Нуркова 2000]. Вербалізація розповіді про дитинство представляє малоусвідомлену авторську позицію. Зміни епохта суспільноісторичних формацій викликають до життя різні принципи співвідношення спомину та тексту.

Суто літературознавчий аспект проблеми представлений сьогодні широкою джерельною базою, яка характеризується багатовекторністю наукових пошуків (Л. Мироненко, І. Старовойт, Б. Шалагінов, І. Шайтанов). Дослідники констатують існування різних наративних моделей автопрезентації. Дитинство може бути представлене «втраченим раєм», в який автобіограф прагне подумки повернутися. Інколи період дитинства нагадує «жах», який все-таки треба знову пережити та переосмислити. Образ дитинства як «стартового майданчика» для дорослого життя відкриває витоки авторської індивідуальності. Така модель відображає епоху дитинства як грунт, на якому сформувався автобіограф. У різні історичні епохи домінує певний варіант літературної презентації дитинства.

Насамперед конкретизуємо сам термін «дитинство», оскільки кожна вікова дефініція має декілька аспектів. Це і біологічний вік, і соціальний вік, i психічний вік. Історично поняття дитинства пов'язане із соціальним статусом індивіда, з його правами та обов'язками [Кованова 2005:66-68]. Зазначимо, що своє активне відображення в художній літературі знаходить проблема взаємодії дитини та дорослого світу, впливу дитячої субкультури на внутрішній світ маленьких героїв.

Література, навідміну від інших видів мистецтва, володіє надзвичайно широким спектром репрезентації феномену дитинства. Оскільки вона звертається «... в равной мере к явлению и сущности, к внешнему и внутреннему, имманентному и трансиендентальному в детстве. Рефлексия детства $u$ юности возможна в литературе с позиций субъекта и объекта с акцентами на 
историческом и сочиальном, психологическом и физиологическом, духовном $и$ телесном его содержании» [Кон 2003:167].

Коротко звернемося до історичного матеріалу. До XVIII-го століття у фокусі літературної уваги виявляється доля вже дорослої, сформованої людини. Дитинство $є$ предметом осмислення лише як складова дорослої людини та оцінюється 3 точки зору успішного чи неуспішного втілення іiі ціннісних установок. Розкриття долі автобіографічного героя поза зв'язком 3 його дитинством свідчить про визнання принципово різної природи цих етапів людського життя в літературній свідомості [Бронская 2001:27].

XVIII століття збагатило європейську літературу біографією дитинства. Воно відкриває важливий етап в розвитку біографічної літератури. Цьому великою мірою сприяв просвітницький роман, зокрема роман-виховання, а також неабиякий розквіт мемуаристики. Саме в цей час чітко розмежовуються дитячий та дорослий світи. Сентименталізм розробив художній образ дитини, зокрема в художній літературі.

Засновниками нової парадигми визнано Лоренса Стерна (1713-1768) 3 його «Життям і заувагами Тристрама Шенді» [Стерн Лоренс 1968] і Жан-Жака Руссо (1712-1778) з його «Сповіддю» [Руссо 2002]. У цих творах пролунала новаторська думка, що переживання дитини можуть бути не тільки цікавими 3 психологічного погляду, а й повчальними у тому сенсі, як вони кидають світло на життя дорослої людини та на весь світ дорослих. У Стерна образ дитинства постає естетичною грою, де гравець - дорослий автобіограф, а змістом гри $є$ мозаїчна за формою репрезентація крізь призму раннього дитинства власного дорослого життя, додаючи активну рефлексію про нього. Це було друге, епохальне, після «Сповіді» Св. Августина [Августин 1999], відкриття історизму власного життя. До речі, Св. Августин розпочинає свою автобіографічну сповідь саме розповіддю про своє дитинство.

Автобіографічна книга Стерна складається 399 частин. Можна стверджувати, що Стерн торкається у ній вічних проблем просвітницької літератури, але робить це вже зовсім по-іншому. Центральним у його 
автобіографічній книзі є питання людської природи, зокрема природи дитини, та різноманітних способів іiі відтворення. 3 традиційного для того часу повчання автобіограф переносить основний акцент на детальне вивчення характеру героя. Він не тільки розповідає про ті чи інші вчинки, але й досліджує різноманітні причини, що їх викликали. Як зазначають історики літератури, тим самим на місце історії людського життя вже приходить «біографія душі» [Сидорченко 2001:205]. Однак дитячі образи, як і сам образ дитинства, у Стерна ще досить схематичні.

Побутує думка, що «відкриття теми дитинства» відбулося саме в рамках протестантизму та пояснюють цей факт особливою вимогою протестантів до навчання дитини, зокрема до вивчення дитиною Біблії (І. Кошелєва). Але більшість тогочасних автобіографів у своїх розповідях про дитинство активно використовують стереотипні наративні моделі та автобіографічні кліше, не акцентуючи особливість свого автобіографічного героя.

Епоха Просвітництва постулювала не лише виховання, а й навчання дитини як активного мислителя та перетворювача світу, на що постійно звертав увагу Руссо. Мету виховання Руссо вбачає у вільному розвитку дитини, яка не залежить від суспільних норм поведінки, керується внутрішнім природним інстинктом. Руссо вважає, що дитина повинна сама вчитися існувати в суспільстві, шукаючи власні ціннісні орієнтири та вподобання.

Суть концепцій Руссо зводиться до створення ситуацій, у яких страждання або позитивні емоції інших людей повинні зачепити дитину внутрішньо так, щоб вона змогла випробувати та пережити почуття співчуття, милосердя, жалю, радості або щастя. Всі ці педагогічні позиції знайшли своє відображення і в літературній творчості Руссо. У книзі «Еміль, або про виховання» (1762) Руссо просто закликає читача любити дитинство, бути уважними до його ігор та забав, до його милого інстинкту [Руссо 1981:24]. Зауважимо, що перші наукові вчення стосовно проблеми дитинства належали I. Канту, I. Фіхте. Їх роздуми згодом актуалізували як спогади про своє 
дитинство Ф. Ніцше, Ж.-П. Сартр. Продовжили філософську рефлексію дитинства крізь призму стосунків з дорослим світом М. Бубер, Ж. Лакан.

В англійському сентименталізмі, як наголошує Б. Шалагінов, відкриття історизму дитинства відбулося дещо раніше. Дослідник пов'язує його 3 творчістю Генрі Філдінга (1707-1754). Руссо взявся до написання своєї «Сповіді» вже збагачений досвідом онтологічного історизму Філдінга та психологічної рефлексії Стерна. Це виявилося в творчості Руссо втому, що він чітко позначив естетичну та етичну диспозицію не просто власного дитинства, а будь-якого дитинства, дитячих років узагалі, як шлях від природи до цивілізації [Шалагінов 2008:89].

Змужніння постає як шлях вимушеної чи навмисної трансформації всього того в людині, що первісно було пов'язане з природою, як шлях долучення до цивілізованих норм поведінки. Роль, яку Руссо відводить дитині, стала революційною для свого часу. Проте в епоху Просвітництва дитинство ще не $\epsilon$ самоцінним періодом, лише допоміжним етапом становлення особистості. Тема дитинства в художній творчості носить виховний характер, що пояснюється тогочасною посиленою увагою до виховання взагалі.

Лише епоха романтизму створює своєрідний культ дитини та дитинства. Романтизм робить дитинство предметом захоплення та мрій. Однак він позбавляє дитину індивідуальних рис, представляючи іiі як символ невинності, якого так не вистачає дорослим [Шалагінов 2008:9]. Остаточне літературне оформлення тема дитинства отримала лише в XIX столітті. Г. Попова зазначає, що в мемуарах доби романтизму тема дитинства зазнає подальшого розвитку, набуваючи нового змісту. В ній утілюється одвічний романтичний конфлікт між ідеалом i дійсністю. Образ дитини урізноманітнюється порівняно 3 просвітницькою традицією, набуває дедалі більш індивідуальних рис [Попова 2006:12]. В автобіографічних творах частою $\epsilon$ вказівка на позитивну роль батьків у вихованні героя. У більшості випадків період дитинства асоціюється з роками навчання. У своїй «Сповіді» Руссо прославляв природні 
якості дитини - спонтанну енергію, безпосереднсть, - які тогочасна традиційна система виховання намагалися пригнітити.

Тема дитинства відображала в собі всі парадигмальні поняття доби Просвітництва: першообраз, розвиток від простого до складного, елемент i система, цільність, полярність і зростання, історизм, гуманність і терпимість, природа і цивілізація [Шалагінов 2008:89]. Проте говорити про тріумфальне поширення теми дитинства в європейській спогадовій літературі XVIII-го століття не можна. Серйозних випробовувань вона зазнала в Англії з приходом промислового капіталізму, який відзначався жорстокістю стосовно всього дитячого. Проте літературна ідея дитинства не зникла, а збагатилася новими смислами, новими яскравими автобіографічними творами.

Гете ініціює тему дитинства та пов'язаний 3 нею образ дитини у «Стражданнях молодого Вертера» (1774), постулюючи просвітницьку концепцію «вільного виховання» Песталоцці 3 елементами християнської міфології. Цей твірвиник, як відомо, на біографічній основі. Зображені в романі діти приносять „неабияке задоволення” Вертеру [Гёте 1978:14]. Згадаймо, як Гете малює побачену ним сцену 3 хлопчиком, який сидів на землі та двома руками пригортав до себе іншу дитину, що сиділа у нього на колінах, так що старша дитина наче служила кріслом для меншої [Гёте 1978:14].

I ще один прекрасний момент, який Вертеру довелося побачити, пов’язаний з дітьми [Гёте 1978:19]. Мова йде про епізод, коли Лотта роздавала своїм братикам та сестричкам хліб. У цьому епізоді Лотта наче поєднує себе та молодших дітей невидимими нитками: «Она держала в руках каравай черного хлеба, отрезала окружавиим ее мальшим по куску, сообразно их годам и aпnетиту, и ласково оделяла каждого» [Гёте 1978:19]. У цьому романі Гете конструює міфологему дитинства в тісному зв’язку 3 міфологемою матері, ідеалізуючи тим самим дитинство та готуючи проростання думки романтиків про життя дитини на «долоні богів».

Згодом Гете відходить від ідеалізованого погляду на дитинство. I хоч один 3 героїв у «Роках навчання Вільгельма Майстера» (1796) говорить, що «...нет 
зрелища прекраснее, чем мать с ребенком на руках, и зрелища достойнее, чем мать в кругу детей» [Гёте 1978:386], центральним персонажем стає образ дитини, який продукує конфлікт дитячої винятковості та бюргерського світу, сповненого узаконених норм поведінки. Звернувшись до теми дитинства, Гете осмислює їі саме в просвітницькому руслі, часто апелюючи до біблійних текстів та педагогічних систем. Згодом в «Роках мандрів Вільгельма Майстера» (1829) Гете підсумує, що вихователю треба слухати дитинство, а не дитину [Гёте 1979:420].

Своє закономірне місце в ряді європейських автобіографічних творів посідає «Поезія і правда» Гете, яка представляє особливий погляд літньої людини на своє дитинство. Міфологема дитинства в автобіографії Гете складається 3 таких елементів: підкорегованих автором актуалізованих архетипів колективного підсвідомого, створених письменником багаторівневих символічних конструкцій. I все це вибудовується на фоні надзвичайного пафосу винятковості автобіографа. Гете безпосередньо сприяє формуванню майбутнього романтичного образу дитини та освоєнню міфопоетичного тону, пов’язаного з цим образом. Однак ранній дитячий вік залишається за межею художнього інтересу, стосовно нього Гете не вважає за потрібне вдаватися до роздумів та пошуків, які до нічого не приведуть [Цяпа 2006:8].

Наголосимо, що XVIII століття розуміло дитину як дорослого маленького формату, навіть одягало дітей в такі камзольчики, дітки носили парички 3 косичкою і завжди ходили при шпазі. Такий опис Гете-дитини неодноразово зустрічаємо в «Поезії і правді» [Goethe1967:104]. Гете не цінує дітей самих по собі, а лише як кандидатів в майбутні дорослі, особливу дитину як кандидата на майбутню екстраординарну особистість. В нього відсутня позиція романтиків, що саме в дітях є максимум можливостей. Тому романтики шукають в дітях та втілюють в дитячих образах те, що буде втрачено дорослими [Берковский 2001:31].

Тема дитинства, представлена в європейській спогадовій літературі XVIII-XIX ст., різноманітна. У ній бачимо традиції позитивного осмислення 
(веселого, радісного) та онтологічну уяву про дитину, розуміння іï життя та світогляду. Майже всі автори представляють чистоту дитячої душі, iï сприйняття добра, любові, жалю та співчуття. Дитячі образи допомагають дорослим побачити й світ, який сприймає не тільки людське око, а насамперед людська душа.

\section{БІБЛІОГРАФІЯ}

Августин 1999. - Августин. Сповідь / Святий Августин ; [пер. $з$ латин. Ю. Мушака ; післям. С. Здіорука]. - К. : Основи, 1999. - 319 с.

Берковский 2001 - Берковский Н. Я. Романтизм в Германии / Н. Я. Берковский. - СПб. : «Аз-бука-классика», 2001. - 568 с.

Бондарева 2006 - Бондарева Л. М. К проблеме организации текстового пространства в немецкоязычном автобиографическом дискурсе / Л. М. Бондарева // Вестник Российского государственного университета им. И. Канта. Вып. 2 Филологические науки, Калининград : Из-во РГУ им. И. Канта, 2006. - С. 69-74.

Бронская 2001 - Бронская Л. И. Концепция личности в автобиографической прозе русского зарубежья первой половины XX века / Бронская Л. И. - Ставрополь : Изд-во СГУ, 2001. - 120 с.

Гёте 1978 - Гёте И. В. Страдания юного Вертера [пер. с нем. Н. Касаткиной] / И. В. Гёте // Собр. соч. : в 10 т. - Т. 6. - М. : Художественная литература, 1978. - С. 5-102.

Гёте 1978 - Гёте И. В. Годы учения Вильгельма Мейстера Вертера [пер. с нем. Н. Касаткиной] // Собр. соч.: в 10 т. - Т. 7. - М. : Художественная литература, 1978. - С. 5-504.

Гёте 1979 - Гёте И. В. Годы странствий Вильгельма Мейстера, или Отрешенные Вертера [пер. с нем. С. Ошерова] // Собр. соч. : в 10 т. - Т. 8. - М. : Художественная литература, 1979. - С. 5-425. 
Кованова 2005 - Кованова Е. А. Риторика автобиографического дискурса (на материале автобиографий американских деятелей политики и искусства) : автореф. дис. ... канд. филол. наук. - СПб., 2005. - 19 с.

Кон 2003 - Кон И. С. Ребенок и общество / Кон И. С. - М. : Академия, 2003. $-336 \mathrm{c}$.

Нуркова 2000 - Нуркова В. В. Свершенное продолжается : Психология автобиографической памяти личности / В. В. Нуркова. - М. : Изд-во УРАО, 2000. -320 c.

Попова 2006 - Попова Г. В. Романтична поетика «Замогильних нотаток» Ф.-Р. де Шатобріана : автореф. дис. на здобуття наук. ступеня канд. філол. наук : спец. 10.01.04 - література зарубіжних країн / Г. В. Попова. - Дніпропетровськ, 2006. $-19 \mathrm{c}$.

Руссо 1981 - Руссо Ж.-Ж. Эмиль, или о воспитании / Руссо Ж.-Ж. Педагогические сочинения в 2 томах [под. ред. Г. Н. Джибладзе] - Т. 1. - М. : «Педагогика», 1981. - 655 с.

Руссо 2002 - Руссо Ж. Ж. Исповедь / Руссо Ж. Ж. ; [пер. с фр. Д. Горбова и М. Розанова. Автор предисловия И. Верцман]. - М. : ЭКСМО, 2002. - 640 с.

Сидорченко 2001 - Сидорченко Л. В. История зарубежной литературы XVIII века : Учеб.для филол. спец. вузов / Л. В. Сидорченко, Е. М. Апенко, А. В. Белобратов и др. ; Под ред. Л. В. Сидорченко. - 2-е изд., испр. и доп. М. : Высшая школа, 2001. - 335 с.

Стерн 1968 - Стерн Лоренс. Жизнь и мнения Тристрама Шенди, джентельмена / Стерн Лоренс ; [пер. с анг. А. Франковского]. - М. : Художественная литература, 1968. - 715 с.

Цяпа 2006 - Цяпа А. Г. Автобіографія як проекція творця та національної літературно-культурної традиції (Улас Самчук, Еліас Каннеті) : автореф. дис. на здобуття наук. ступеня. канд. філол. наук : спец. 10.01 .05 - порівняльне літературознавство / А. Г. Цяпа. - Тернопіль, 2006. - 23 с.

Шалагінов 2008 - Шалагінов Б. Великий світ маленького дитинства / Б. Шалагінов, Н. Назаров // Всесвіт. - 2008. - № 5-6 - С. 166-171. 
Goethe1967 - Goethe Johann Wolfgang. Poetische Werke // Werke in 16 Bänden [2. Auflage]. Anmerkungen und Erläuterungen : Hans-Heinrich Reuter, Annemarie Noelle, Gerhardt Seidel / Goethe Johann Wolfgang. Band 13. : Aus meinem Leben. Dichtung und Wahrheit. Berlinund Weimar : Aufbau-Verlag, 1967.$1050 \mathrm{~s}$. 